\title{
Genetic divergence among Nellore breed herds raised in the South Region of Brazil
}

\author{
Divergência genética entre rebanhos da raça Nelore criados na região Sul do Brasil
}

\author{
Jader Silva Lopes ${ }^{I}$ Paulo Roberto Nogara Rorato ${ }^{\mathrm{I}}$ Tomás Weber $^{\mathrm{I}}$ \\ Ronyere Olegário de Araújo ${ }^{\mathrm{I}}$ Dionéia Magda Everling ${ }^{\mathrm{I}}$ Tiago Bresolin ${ }^{\mathrm{I}}$ \\ Mariana de Almeida Dornelles ${ }^{\mathrm{I}}$ Fernanda Cristina Breda ${ }^{\mathrm{I}}$
}

\begin{abstract}
The objective of this study was to evaluate the genetic divergence among Nellore breed animals raised in 45 farms in the Southern Region of Brazil. The characteristic studied was weaning weight adjusted to 205 days of life (P205), from 10,874 animals sired by 425 bulls and 7,629 cows, collected between 1976 and 2001, and distributed in the states of Rio Grande do Sul (1,499), Santa Catarina (2,332) and Parana (7,043). The animals were distributed by cluster analysis in eight genetic divergent groups, enabling this technique to be applied to organize the matings in order to obtain heterotic effect. The herd/farm groups were formed through the hierarchical Ward method, using the direct (VGD) and maternal (VGM) breeding values predicted by the REML method. The VGD of the animal accounted for $90 \%$ of the differences among herds, and the remaining $10 \%$ was attributed to differences in the VGM. On average, the P205 for the animals from inter-group mating was $1.4 \mathrm{~kg}$ higher than those from intragroup mating, representing $2.4 \%$ of heterosis.
\end{abstract}

Keywords: cluster analysis, genetic diversity, multivariate analysis, similarity, Ward hierarchical method.

\section{RESUMO}

O objetivo deste trabalho foi avaliar a divergência genética entre animais da raça Nelore criados em 45 fazendas situadas na região Sul do Brasil, participantes do serviço de Controle de Desenvolvimento Ponderal da Associação Brasileira de Criadores de Zebu. A característica estudada foi o peso à desmama, ajustado para 205 dias de idade (P205), de 10.874 animais, filhos de 425 touros e de 7.629 vacas, nascidos entre 1976 e 2001, assim distribuídos: 1.499 no estado do Rio Grande do Sul, 2.332 no de Santa Catarina e 7.043 no do Paraná. Os animais foram distribuídos, por meio de análise de agrupamento, em grupos geneticamente divergentes, o que possibilitou a aplicação dessa técnica para direcionar acasalamentos, visando a obter efeito heterótico. $O$ método hierárquico de Ward foi utilizado para formar os grupos de rebanhos/fazendas a partir dos valores genéticos aditivos, direto (VGD) e materno (VGM), preditos pelo REML. O VGD dos animais foi responsável por 90\% da contribuição para as divergências entre fazendas, sendo os $10 \%$ restantes atribuídos às divergências entre os VGM. O $P 205$, verificado para os animais oriundos de acasalamentos inter-grupos, foi $1,4 \mathrm{~kg}$ maior do que o dos animais produzidos por acasalamentos intra-grupos, representando uma superioridade de $2,4 \%$.

Palavras-chave: análise multivariada, análise de agrupamento, diversidade genética, método hierárquico de Ward, similaridade.

\section{INTRODUCTION}

The main goal of animal breeding studies on genetic diversity among sire groups is the identification of hybrid combinations with high heterozygosis to increase the possibility of recuperating the superior genotypes in the segregating generations (VIANA et al., 2000).

In the Nellore breed, according to LÔBO et al. (2003), despite the small number of sires responsible for the breed formation, there is evidence of different genetic profiles among the lines, according to the selection criteria adopted during their formation. In this context, in-line mating is widely applied in the formation of different lines within breeds in order to generate different families within the population and allow the selection of the best specimens as well as the elimination of the

IDepartamento de Zootecnia, Universidade Federal de Santa Maria (UFSM), 97105-970, Santa Maria, RS, Brasil. E-mail: prrorato@gmail.com.*Autor para correspondência. 
worst. This mating method is most commonly used in the Nellore breed, consisting of a very important tool in the preservation of certain imported genotypes (MAGNABOSCO et al., 1997).

The term "line" is applied to a group of genetically related animals, derived from a sire that was used in the foundation of Nellore breed, a genetic material which was imported in the 1960s (MAGNABOSCO et al., 1997). The idea of relationship in animal breeding means genotype similarity; two animals are considered related when the probability of them having genes in common is higher than for any two other animals in the population.

Genetic diversity among lines in Nellore breed can be evaluated through genetic divergence studies (CRUZ\& REGAZZI, 1997). These studies can assess genotype behavior in different environments, determine the superiority of certain genotypes over others, identify divergent genotypes that can be used as sires in hybridization programs, and relate genetic divergence with heterosis (PIASSI, 1994). Moreover, they identify hybrid combinations with higher heterotic effect and heterozygosis; thereby, enabling the improvement of recovering superior genotypes in segregating generations (CRUZ \& REGAZZI, 1997).

In many types of biological data, variables are correlated; thus, information provided by univariate analysis may be incomplete. Therefore, the use of a multivariate analysis technique is more effective in the prediction of genetic divergence, since they relate multiple types of information from an experimental unity. Among these techniques, analysis by main components, analysis by canonical variables, and cluster analysis can be cited.

The multivariate analysis technique of grouping enables the formation of homogeneous groups by a scheme that gathers data in groups with a high degree of internal homogeneity and a high degree of heterogeneity among them (JONHSON \& WICHERN, 1998).

The objective of this study was evaluate the genetic divergence among groups (farms) of Nellore breed animals raised in the Southern Region of Brazil by cluster analysis and the application of this technique with the aim of organizing matings to obtain a better heterotic effect.

\section{MATERIAL AND METHODS}

Records on 10,874 animals born in the states of Rio Grande do Sul (RS) $(1,499)$, Santa Catarina (SC) $(2,332)$ and Paraná (PR) $(2,043)$, from
1976 to 2001 , were used to estimate the (co)variance components of the genetic parameters and breeding values for the characteristic weaning weight adjusted to 205 days of age (P205). These animals were sired by 425 bulls and 7,629 cows and were distributed throughout 45 farms which participate in the weight control program of the Brazilian Association of Zebu Breeders (Associação Brasileira de Criadores de Zebu, ABCZ).

Six hundred and sixty nine groups of contemporaneous (GC) were defined, constituted by animals of the same sex, management and feeding system, born in the same state, herd in the same year and season. The year was divided into two breeding seasons, according to the climate and rain regimen of the Southern Region (April-September/ OctoberMarch). The management system was divided into two groups: 1) suckling and 2) not suckling at 205 days of age. The feeding system was divided into three groups: 1) animals raised extensively on grass pastures receiving protein and mineral salt (59\% of the data); 2) animals raised semi-extensively, receiving voluminous (bulky) or concentrated food supplementation or which had access to pastures consorted by grass and leguminous (11\%); and 3) animals receiving all foods, ration concentrate, hay and/or silage, at the trough.

Data from bulls with less than five offsprings, farms with less than twenty animals, groups of contemporaneous with less than five animals, cows with age superior to fifteen years and inferior to two and bulls with progenies in only one group of contemporaneous were excluded from the data file.

The (co)variance components used to estimate the genetic parameters and breeding values were obtained through the Method of Derivative Free Restricted Maximum Likelihood (MTDFREML) by BOLDMAN et al. (1995). A simplex algorithm was used to obtain the -2 Log of the Likelihood function, which is the maximum likelihood estimative for these components. The convergence criterion considered was $1 \times 10^{-9}$.

The general model for the analysis can be described as $\mathrm{y}=\mathrm{X} \beta+\mathrm{Z}_{1} \mathrm{a}+\mathrm{Z}_{2} \mathrm{~m}+\mathrm{e}$, where $\mathrm{y}=$ vector of the observations for the characteristic P205; X = matrix of incidence associated with fixed effects (group of contemporaneous); $\beta=$ vector of the solutions for fixed effects; $Z_{1}=$ matrix of incidence associated with direct additive genetic effects; $Z_{2}=$ matrix of incidence associated with maternal additive genetic effects; $\mathrm{a}=$ vector of the animal direct additive genetic effect; $\mathrm{m}=$ vector of the maternal additive genetic effects; $\mathrm{e}=$ vector of residuals . 
The presuppositions assumed in relation to the vectors $y, a, m$ and $e$ were: $\mathrm{E}[\mathrm{y}]=\mathrm{X} \beta$; $\operatorname{Var}(\mathrm{a})=\mathrm{A} \otimes \mathrm{G}_{\mathrm{a}}, \quad \operatorname{Var}(\mathrm{m})=\mathrm{A} \otimes \mathrm{G}_{\mathrm{m}}, \quad \operatorname{Var}(\mathrm{e})=\mathrm{I} \otimes \mathrm{R}_{\mathrm{e}}$, where $G_{a}$ is the matrix of the direct additive genetic covariance; $G_{m}$ is the matrix of the maternal additive genetic covariance; $R_{e}$ is the matrix of the residual covariance; $\mathrm{A}$ is the numerator matrix of genetic additive relations; I is the identity matrix; and $\otimes$ is the direct product between matrixes. It was also assumed that the vectors $a, m$ and $e$ are not correlated. The following suppositions were assumed: $\mathrm{E}(y)=\mathrm{X} \beta$, $\mathrm{E}(\mathrm{a})=\mathrm{E}(m)=\mathrm{E}(e)=0, \operatorname{Var}(y)=\mathrm{Z}_{1} \mathrm{AZ}_{1}{ }^{\prime} \sigma_{a}^{2}+\mathrm{Z}_{2} \mathrm{AZ}_{2}{ }^{\prime} \sigma_{m}^{2}+$ $\mathrm{R}, \operatorname{Var}(\mathrm{a})=\mathrm{A} \sigma_{a}^{2}, \operatorname{Var}(m)=\mathrm{A} \sigma_{m}^{2}, \operatorname{Var}(\mathrm{e})=\mathrm{I} \sigma_{e}^{2}$; where A $=$ relationship matrix, $\mathrm{I}=$ identity matrix, $\mathrm{R}=$ residual variance and covariance matrix, $\sigma_{a}^{2}=$ direct additive genetic variance component, $\sigma_{m}^{2}=$ maternal additive genetic variance component, $\sigma_{e}^{2}=$ residual variance component.

The permanent environmental effect of the cow was not considered in the model because the average of parturition/cow was only 1.43.

The hierarchic Ward method was used to form the farm groups considering the predicted direct and maternal additive genetic values. Its main characteristic is to form homogeneous groups (SHARMA, 1996; JONHSON \& WICHERN, 1998).

The Ward Method of Minimum Variance is biased to form groups of the same size, from the sum of squared errors (SSE) of each cluster (sum of squared deviations for each centroid of the cluster). The SSEs of all $\mathrm{G}$ clusters are added together, generating the total sum of squared errors (TSSE). The method consists of analyzing all possible pairs of clusters, detecting the combination which produces the least increase of SSE. In this method the distance between two clusters is the sum of the squares between them, for all the variables. In each generation the intra-cluster SSE decreases. Frequently the use of the ratio SSE/TSSE is suggested instead of the SSE. The dissimilarity measure is defined by

$$
D_{K, L}=\frac{d\left(\bar{x}_{K}, \bar{x}_{L}\right)^{2}}{\left(\frac{1}{N_{K}}+\frac{1}{N_{L}}\right)}
$$

If the Euclidian distance is to be used, the equation becomes

$$
D_{K, L}=\frac{\left\|\bar{x}_{K}-\bar{x}_{L}\right\|^{2}}{\left(\frac{1}{N_{K}}+\frac{1}{N_{L}}\right)}
$$

This method aims to maximize likelihood in each hierarchic level considering the hypothesis of mixture of normal multivariates, equal covariance spherical matrixes, and to equal sampling probabilities. It tends to unite the clusters with small number of observations and it is strongly biased to produce clusters with the same shape and number of observations. It is also very sensitive to outliers.

To define the number of groups, the Pseudo F measure by CALINSKI \& HARABASZ (1974) was used, in which an elevated value of this statistic, when compared with the previous, indicates the stop point, as well as the dendrogram. This analysis was developed by the PROC CLUSTER e TREE procedure from SAS (SAS, 2001).

The measures of genetic divergence and of the heterotic effect were obtained by the comparison of the weight average at 205 days of age estimated for the intra-group matings with the inter-group matings progenies.

\section{RESULTS AND DISCUSSION}

The average weaning weight adjusted to 205 days of age $(\mathrm{P} 205)$ was $169.7 \pm 30.7 \mathrm{~kg}$. This value is close to that reported for Nellore breed by ELER et al. (2000) in the Southeastern and West Central Brazilian Regions and by TORAL et al. (2004) in the State of Mato Grosso do Sul. However this value is superior to those reported for the same breed by CUBAS et al. (2001) in the State of Paraná and by FERREIRA et al. (2001) in the State of Minas Gerais.

The direct heritability estimated for P205 was $0.28 \pm 0.05$. This value is close to those estimated by ELER et al. (2000), FERREIRA et al. (2001) and TORAL et al. (2004), ranging from 0.16 to 0.59 ; however it is superior to those related for the Nellore breed by RIBEIRO et al. (2001) and SILVEIRA et al. (2004), respectively 0.16 and 0.17 , suggesting that, in these two populations, environmental influence had a stronger effect on the animals' performance; or yet that the biggest number of collected observations from a big number of farms with heterogeneous management could have maximized the environmental variance, underestimating the heritability estimative.

The maternal heritability expresses the capacity of the cow to raise her progenies and, therefore, it is of great importance in selection programs (LOPES et al., 2008). The maternal heritability estimated for P205 was $0.20 \pm 0.03$, a higher value than those estimated by ELER et al. (2000), FERREIRA et al. (2001), RIBEIRO et al. (2001) and SILVEIRA et al. (2004) which range from 0.06 to 0.16 . This suggests a higher influence of maternal heritability on the progenies performance in the studied population. 
The 45 farms were divided in 8 groups (Pseudo $\mathrm{F}=560$ ). The animals breeding value was responsible for $90 \%$ of divergences among farms, and the other $10 \%$ was attributed to divergences between the maternal additive genetic values.

The average distance (D) between farms was 0.0202. According to SILVEIRA NETO (1986), it is not valid to extrapolate these patterns because the dissimilarity of the measures is specific for the populations included in the study.

Figure 1 displays the degree of similarity among sires, among sires in similar groups or between two distinct groups. In this case the groups are subjectively constituted, based on the changes between levels associated to the researcher's previous knowledge about the evaluated sires. At the final step of the grouping process it is necessary to evaluate the adequacy of the results because during the dendrogram elaboration considerable simplification of the original information can occur, resulting in distortions on the similarity between the studied genotypes. Thus, the use of dendrograms needs to be very accurate, because the decision on the optimum number of groups is difficult to be visualized, even though the results are usually represented by easily interpretable diagrams (YAMAKI et al., 2008). According to CRUZ \& REGAZZI (1997), many numbers of groups are usually used and, due to an optimization criterion, the most convenient are selected. In this study the Pseudo F was used (Figure 1).
In order to evaluate the application of this technique to direct matings towards a higher heterotic effect, average weights at 205 days in animals resulting from intra-group matings were compared to those in animals resulting from inter-group matings (Table 1).

In average, animals resulting from intergroup matings presented a weaning weight (P205) $1.4 \mathrm{~kg}$ higher than those resulting from intra-groups. This superiority represents a heterotic effect equal to $2.4 \%$, i.e. $30 \%$ of the value reported by MUNIZ \& QUEIROZ (1998) to weaning weight at 240 days of age for products of Nellore-Gelbvieh cross-breeding in the State of Mato Grosso do Sul. However, the heterosis observed in this study represents only $16 \%$ of the value obtained by BARBOSA \& ALENCAR (1995) in cross-breeding studies between B. taurus and B. indicus conducted in Brazil from 1934 to 1994 for features such as growth speed.

According to ALENCAR et al. (1995), one of the factors that account for the superior quality of crossbreeds in relation to purebreds of the original races is the genetic difference between the breeds used in the crossing. This may explain the inferiority of heterosis values in cross-breeding within the same race in relation to those found in inter-race crossbreeding and in cross-breeding between B. Taurus and B. indicus.

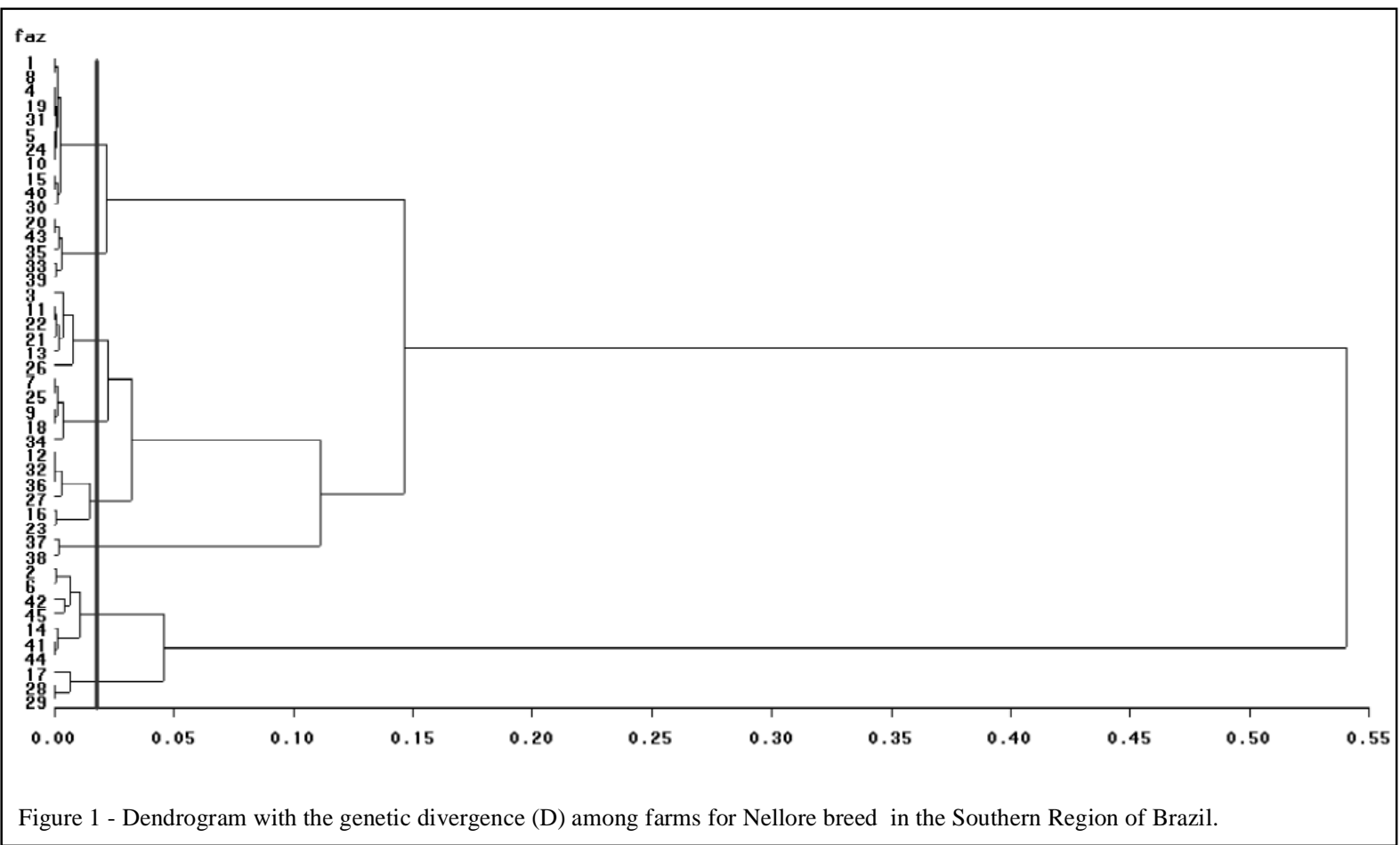

Ciência Rural, v.43, n.5, mai, 2013. 
Table 1 - Intra-group and inter-group matings, number of observations/matings, average weight adjusted to 205 days of life, in kilograms, minimum and maximum weight/mating, in kilograms.

\begin{tabular}{|c|c|c|c|c|c|}
\hline Group & Group & Observations & Average & Minimum & Maximum \\
\hline 1 & 1 & 4 & 164 & 113 & 205 \\
\hline 1 & 2 & 284 & 167 & 86 & 253 \\
\hline 1 & 3 & 13 & 189 & 147 & 242 \\
\hline 1 & 4 & 30 & 176 & 111 & 242 \\
\hline 1 & 5 & 4 & 193 & 166 & 223 \\
\hline 1 & 6 & 9 & 182 & 148 & 216 \\
\hline 1 & 7 & 2 & 149 & 138 & 159 \\
\hline 1 & 8 & 1 & 182 & 182 & 182 \\
\hline 2 & 2 & 2,752 & 168 & 84 & 260 \\
\hline 2 & 3 & 436 & 180 & 88 & 256 \\
\hline 2 & 4 & 4,389 & 170 & 83 & 261 \\
\hline 2 & 5 & 807 & 168 & 84 & 254 \\
\hline 2 & 6 & 666 & 177 & 91 & 258 \\
\hline 2 & 7 & 434 & 172 & 89 & 257 \\
\hline 2 & 8 & 39 & 162 & 98 & 254 \\
\hline 3 & 3 & 24 & 177 & 142 & 232 \\
\hline 3 & 4 & 173 & 184 & 114 & 257 \\
\hline 3 & 5 & 21 & 192 & 125 & 243 \\
\hline 3 & 6 & 45 & 187 & 124 & 253 \\
\hline 3 & 7 & 40 & 172 & 136 & 255 \\
\hline 4 & 4 & 166 & 169 & 99 & 261 \\
\hline 4 & 5 & 30 & 171 & 101 & 213 \\
\hline 4 & 6 & 186 & 180 & 108 & 259 \\
\hline 4 & 7 & 92 & 173 & 94 & 261 \\
\hline 4 & 8 & 5 & 186 & 151 & 227 \\
\hline 5 & 5 & 1 & 178 & 178 & 178 \\
\hline 5 & 6 & 39 & 171 & 118 & 214 \\
\hline 5 & 7 & 15 & 183 & 158 & 250 \\
\hline 5 & 8 & 2 & 168 & 165 & 171 \\
\hline 6 & 6 & 92 & 168 & 98 & 252 \\
\hline 6 & 7 & 56 & 153 & 91 & 244 \\
\hline 6 & 8 & 1 & 166 & 166 & 166 \\
\hline 7 & 7 & 15 & 164 & 129 & 196 \\
\hline 7 & 8 & 1 & 196 & 196 & 196 \\
\hline
\end{tabular}

\section{CONCLUSION}

This study indicates that above breeding value, attention should be paid to the origin of the sire and/or semen to be used, because the higher the genetic divergence between the sire and the dams, the higher will be the heterozygosis and the gain with heterosis improving the profit gain.

\section{REFERENCES}

ALENCAR, M.M et al. Peso à desmama de bezerros da raça Nelore e cruzados Canchim x Nelore e Marchigiana x Nelore. Revista Brasileira de Zootecnia. v.24, n.6, p.917-925, 1995. Disponível em: 〈http://www.sbz.org.br/revista/artigos/401.pdf〉. Acesso em: 20 jun. 2011.

BARBOSA, P.F; ALENCAR, M.M. Sistema de cruzamentos em bovinos de corte: estado da arte e necessidades de pesquisa. 
In: REUNIÃO ANUAL DA SOCIEDADE BRASILEIRA DE ZOOTECNIA, 32., 1995, Brasília, DF. Anais... Brasília: Sociedade Brasileira de Zootecnia, 1995. p.681-683.

BOLDMAN, K.G. et al. A manual for use for MTDFREML. A set of programs to obtain estimates of variance and covariances (Draft). Lincoln: Departament of Agriculture/Agricultural Research Service, 1995. 120p.

CALINSKI, T., HARABASZ, J. A dendrite method for cluster analysis. Communications in Statistics - Simulation and Computation, v.3, n.1, p.1-27, 1974. Disponível em: <http://www. bibsonomy.org/bibtex/2c343ea63ab0836fa74992f5f5493bb33/ zeno>. Acesso em: 12 jun. 2011.

CRUZ, C.D.; REGAZZI A.J. Modelos biométricos aplicados ao melhoramento genético. 4.ed. Viçosa: UFV, 1997. 514p.

CUBAS, A.C. et al. Desempenho até a desmama de bezerros Nelore e cruzados com Nelore. Revista Brasileira de Zootecnia, v.30, n.2, p.694-701, 2001. Disponível em: <http://www.scielo. $\mathrm{br} / \mathrm{scielo}$.php? pid=S1516-35982001000300013\&script $=\mathrm{sci}_{-}$ arttext>. Acesso em: 20 jun. 2011. doi: 10.1590/S151635982001000300013 .

ELER, J.P. et al. Influência da interação touro $\mathrm{x}$ rebanho na estimação da correlação entre efeitos genéticos direto e materno em bovinos da raça Nelore. Revista Brasileira de Zootecnia, v.29, n.6, p.1642-1648, 2000. Disponível em: <http://www.scielo. $\mathrm{br} / \mathrm{scielo}$.php? $\mathrm{pid}=\mathrm{S} 1516-35982000000600007 \&$ script $=\mathrm{sci}_{-}$ arttext>. Acesso em: 10 jun. 2011. doi: 10.1590/S151635982000000600007 .

FERREIRA, V.C.P. et al. Interação genótipo-ambiente em algumas características produtivas de gado de corte no Brasil. Arquivo Brasileiro de Medicina Veterinária e Zootecnia, v.53, n.3, p.385-392, 2001. Disponível em: <http://www.scielo.br/ scielo.php?script=sci_arttext\&pid=S0102-09352001000300019>. Acesso em: 2 jun. 2011. doi: 10.1590/S0102-09352001000300019.

FRIES, L.A. Maximizar heterozigose ou heterose? In: SIMPÓSIO NACIONAL DE MELHORAMENTO ANIMAL, 1996, Ribeirão Preto, SP. Anais... Ribeirão Preto: Sociedade Brasileira de Melhoramento Animal, 1996. p.252-254.

GIANNOTTI, J.G. et al. Análise de agrupamento para implementação da meta-análise em estimativas de herdabilidade para características de crescimento em bovinos de corte. Revista Brasileira de Zootecnia, v.34, n.4, p.1165-1172, 2005. Disponível em: <http://www.scielo.br/scielo.php?pid=S151635982005000400010\&script=sci_arttext $>$. Acesso em: 10 jun. 2011. doi: 10.1590/S1516-35982005000400010.

JOHNSON, R.A.; WICHERN, D.W. Applied multivariate statistical analysis. 4.ed. Madison, USA: Prentice Hall, 1998. 816p.

LÔBO, R.B. et al. Perfil genético dos principais touros fundadores da raça Nelore na base de dados do PMGRN-USP. In: REUNIÃO ANUAL DA SOCIEDADE BRASILEIRA DE ZOOTECNIA, 40., 2003, Santa Maria, RS. Anais... Santa Maria: Sociedade Brasileira de Zootecnia, 2003. CD-ROM.

LOPES, J.S. et al. Efeito da interação genótipo*ambiente sobre o peso ao nascimento, aos 205 e aos 550 dias de idade de bovinos da raça Nelore na Região Sul do Brasil. Revista Brasileira de
Zootecnia, v.37, n.1, p.54-60, 2008. Disponível em: <http:// www.scielo.br/scielo.php?script=sci_arttext\&pid $=\mathrm{S} 1516$ $35982008000100007 \& \operatorname{lng}=\mathrm{pt} \& \mathrm{nrm}=\mathrm{iso} \&$ tlng $=\mathrm{pt}>$. Acesso em: 12 jun. 2011. doi: 10.1590/S1516-35982008000100007.

MAGNABOSCO, C.U. et al. Catálogo de linhagens do germoplasma zebuíno: raça Nelore. Brasília: Embrapa-Cenargen, 1997. 52p.

MUNIZ, C.A.S.D.; QUEIROZ, S.A. Avaliação do peso a desmama e do ganho médio de peso de bezerros cruzados, no estado do Mato Grosso do Sul. Revista Brasileira de Zootecnia, v.27, n.3, p.504512, 1998. Disponível em: <http://www.revistasbz.org.br/scripts/ revista/sbz1/Artigos/2043.pdf>. Acesso em: 12 jun. 2011.

PIASSI, M.A. Avaliação do desempenho de linhagens de postura mantidas na Universidade Federal de Viçosa, em competição com marcas comerciais. 1994. 86p. Dissertação (Mestrado em Genética em Melhoramento) - Universidade Federal de Viçosa, MG.

RIBEIRO, M.N. et al. Herdabilidade para efeitos direto e materno de características de crescimento de bovinos Nelore no estado da Paraíba. Revista Brasileira de Zootecnia, v.30, n.4, p.1224-1227, 2001. Disponível em: <http://www.scielo. br/scielo.php?pid=S1516-35982001000500014\&script $=$ sci arttext>. Acesso em: 20 jun. 2011. doi: 10.1590/S151635982001000500014 .

SAS Institute. SAS ${ }^{\circledR} 8.1$ for Microsoft Windows. SAS International Cary, 2011.

SHARMA, S. Applied multivariate techniquies. New York: John Wiley, 1996. 512p.

SILVEIRA, J.C. et al. Fatores ambientais e parâmetros genéticos para características produtivas e reprodutivas em um rebanho Nelore no estado do Mato Grosso do Sul. Revista Brasileira de Zootecnia, v.33, n.6, p.1432-1444, 2004. Disponível em: <http://www.scielo.br/scielo.php?pid=s151635982004000600010\&script=sci_arttext $>$. Acesso em: 8 jun. 2011. doi: $10.1590 / \mathrm{S} 1516-35982004000600010$

SILVEIRA NETO, S. Análise genética. In: ALVES, S.B. (Eds.). Controle microbiano de insetos. São Paulo: Manole, 1986. p 384-407.

TORAL, F.L.B. et al. Interação genótipo $\mathrm{x}$ ambiente em características de crescimento de bovinos da raça Nelore no Mato Grosso do Sul. Revista Brasileira de Zootecnia, v.33, n.6, p.1445-1455, 2004. Disponível em: <http://www.scielo.br/ scielo.php?script=sci_arttext\&pid=S1516-35982004000600011 $>$. Acessoem: 10jun. 2011. doi: 10.1590/S1516-35982004000600011.

VIANA, C.F.A. et al. Estudo da divergência genética entre quatro linhagens de matrizes de frangos de corte utilizando técnicas de análise multivariada. Revista Brasileira de Zootecnia, v.29, n.4, p.1074-1081, 2000. Disponível em: <http://www.scielo.br/ scielo.php?script=sci_arttext\&pid=S1516-35982000000400018 $>$. Acessoem: 10jun. 2011. doi: 10.1590/S1516-35982000000400018.

YAMAKI, M. et al. Divergência genética entre linhagens de matrizes de corte por meio de análise de agrupamento. Revista Brasileira de Zootecnia, v.37, n.5, p.829-833, 2005. Disponível em: <http://www.scielo.br/scielo.php?pid=S1516$35982008000500008 \&$ script=sci_arttext $>$. Acesso em: 12 jun. 2011. doi: 10.1590/S1516-35982008000500008. 